\title{
Employers' Investment in Skills: Test of Skills Portability Argument
}

\author{
Zilvinas Martinaitis \\ Kaunas University of Technology \\ Donelaicio 73, LT-44029 Kaunas, Lithuania \\ cross $^{\text {ref }}$ http://dx.doi.org/10.5755/j01.ss.84.2.7488
}

\begin{abstract}
Literature argues that propensity of firmsponsored training depends on portability of skills. The paper seeks to test this hypothesis with the data from 5th European Social Survey that includes 21 EU Member State, Norway and Switzerland. Becker (1993) argued that employers will only invest in training that is of no use to other firms. The data does not support this hypothesis: European firms frequently invest in training that is highly valuable to other firms. Literature on labour market frictions argues that firms are likely to fund training, if the costs of switching employers' are high. Data suggests that the reverse might be true: if individual have many outside options, the odds of receiving firm-sponsored training increases.

Keywords: educational economics, human capital, educational finance, skills portability.
\end{abstract}

\section{Introduction}

It has long been acknowledged that employers play a pivotal role in skills formation systems by investing in the system of apprenticeships and on-the-job training. Becker (1993) paved the way for discussion by arguing that due to threat of poaching firms will pay only for acquisition of firm-specific skills. More recent literature (Acemoglu and Pischke, 1999a, 1999b) suggested that firms will invest even in general skills, if labour market imperfections compress wages so that increases in productivity resulting from training are higher than growth in wage levels. Although recent work has substantially broadened our understanding, two issues remain. First, the notions of specificity or portability of skills remain problematic: why some skills are more portable than others and how does this affect employers' incentives? Second, there is a lack of empirical studies that verify the links between specificityportability of skills and firm-sponsored training. This paper seeks to contribute to solving both problems.

Conceptualisation and definition of specificity/portability of skills is far from straightforward. Here at least two issues arise. First, what factors have an effect on portability/specificity of skills: is it the contents of education/training or labour market structure? Second, what is the unit of employers' decisions, i.e. does it depend on type of training or (portability of skills of) the recipient of sponsored training? Depending on the answers, there are at least four ways to conceptualise and measure portability of skills.

Empirical tests so far have mostly focused on the effects of labour market institutions (minimum wages and unions) on wage compression and firm-sponsored training (see for e.g. Leighton and Mincer, 1981; Grossberg and Sicilian, 1999; Neumark and Wascher, 2001; Arulampalam, Booth and Bryan, 2002; Acemoglu and Pischke, 2003; Dustmann and Schonberg, 2009 among others). The number of empirical studies on the effects of skills portability is considerably smaller and research has mostly concentrated on investments in apprenticeship training (see Franz and Soskice, 1995; Steedman, 1993; Harhoff and Kane, 1997). The main finding is that although the acquired skills are highly portable, apprenticeship systems are generously funded by employers. The problem, however, is that the cited studies did not explicitly measure portability. Geel, Mure and Backes-Gellner, (2011) used skills weights approach and argued that portability of skills acquired during apprenticeships substantially differ by occupations. However, this approach cannot be easily replicated in other countries due to lack of compatible data set.

This paper uses the data of $5^{\text {th }}$ wave of European Social Survey carried out in 2010-2011 in 21 EU Member States as well as Norway and Switzerland. In addition to detailed information on recipient of training, the data set also includes information on perceptions of respondents on the number of firms that could make use of their overall skills-mix (portability of skills) and usefulness of skills acquired during training to other employers. While perceptions by definition are subjective, they reveal how (non)recipient of firm-funded training value the odds of transferring ones skills to other companies. Arguably, this could be more informative than other more objective measures, such sectoral concentration of firms, level of unemployment, etc. The main finding (in contrast to theoretical expectations) is that the odds of receiving firmsponsored training increase with the number of outside options an employee has. Employers also tend to cover the costs of training that is of high value to other firms.

The paper is divided in four parts. The second one discusses different ways to conceptualise skills portability. The third section discusses the data set and operationalization of variables. The fourth section tests the hypotheses and the last one discusses limitations and implications of the results. 
Dimensions and conceptualisations of portability of skills

\begin{tabular}{|c|c|c|c|}
\hline \multirow{4}{*}{ 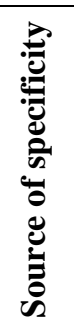 } & & \multicolumn{2}{|c|}{ Which skills matter? } \\
\hline & & $\begin{array}{c}\text { Marginal value of skills acquired in } \\
\text { education and training }\end{array}$ & Overall set of skills an employee has \\
\hline & Labour market structure & $\begin{array}{l}\text { Relevance of education/training to other } \\
\text { employers }\end{array}$ & $\begin{array}{l}\text { Number of outside options an } \\
\text { employee has }\end{array}$ \\
\hline & $\begin{array}{l}\text { Contents of } \\
\text { education/training }\end{array}$ & General v.s. firm-specific training & $\begin{array}{l}\text { Type of training (academic or } \\
\text { vocational) } \\
\text { Tenure }\end{array}$ \\
\hline
\end{tabular}

\section{Skills portability: interpretations and implications}

Current academic debate on firms' investment in training of employees rests on Becker's (1993) distinction between specific and general skills. The latter are said to increase productivity of a worker in many firms, while specific skills are only useful in a specific firm. Becker argued that firms will train, if productivity increases resulting from training will be higher than wage paid by the firm. The latter depends on wage levels that other firms are willing to offer (external wage). If the acquired skills are irrelevant to other firms, training has no effect on external wages. Hence, the above condition is satisfied. However, if training leads to acquisition of general skills, it raises external wage to levels corresponding with productivity. In such cases the worker will be granted a wage equal to external wage and productivity in the training firm or will be poached. As a result, returns from training to the firm are equal to zero or negative. Hence, the main argument is that due to the threat of poaching firms are likely to invest only in non-portable specific skills.

Acemoglu and Pischke (1999a, 1999b) among others extended and modified Becker's explanation. The basic argument is that firms are likely to invest even in general training as long as labour market imperfections compress wages so that increases in productivity resulting from training are higher than growth in wage levels. Literature since has focused on several sources of market imperfections that compress wages. First, external wages are compressed by transaction costs that a worker faces when switching jobs and imperfect information faced by potential employers on the 'true' levels of productivity of trained workers (Acemoglu and Pischke, 1999a, 1999b; Bassani and Brunello, 2003; Bassanini et al., 2005). These mechanisms compress external wages. Second, labour market institutions (such as minimum wage, unions, high levels of unemployment benefits) also compress wages necessary for training to take place (Acemoglu and Pischke, 2003; Booth, Francesconi and Zoega, 2003). Labour market institutions compress internal wages.

The discussion below focuses on factors that affect the costs of switching employers. Two questions in this respect stand out. First, what factors affect portability/specificity of skills: the contents/types of acquired skills or properties of the labour market structure? Second, which skills matter for employers' investment decisions: only the ones acquired in training or a broad set of skills that an employee has? Possible alternatives according to these dimensions are outlined in Table 1.

\section{Type of training or labour market situation?}

The first question refers to the source of portability/specificity of skills. According to the first interpretation, portability stems from the contents and types of education and training: differences in the acquired skills per se affect capacity to switch employers. Accordingly, for example, Varieties of Capitalism literature argues that specific skills are obtained in vocational education and training and further developed during long tenures within a firm, occupation or industry, while general skills are obtained during academic education and short tenures (Estavez-Abe, Iversen and Soskice 2001; Culpepper, 2007; Thelen, 2007). Hence, some types of skills (usually the ones linked with a concrete firm, industry or occupation) are assumed to be less portable than the ones not directly linked with a concrete performance domain. If this correct, then:

H1. Individuals with short tenures and academic education should face lower odds of receiving firm-funded training than employees with long tenures and vocational training.

According to the second interpretation the structure of labour market affects portability of skills. More specifically, the level of portability depends on the number of firms relying on a given set of skills (or monopsony power of current employer) and transaction costs in accessing other labour market segments. The latter is closely related with recognition of qualifications and other obstacles to professional or geographical mobility. In contrast to the first interpretation, this implies that even the broadest skills (for example proficiency in Mandarin language) could be hardly portable, if the number of 'accessible' firms that make use of such skills is small. Conversely, very narrow occupational skills (for example, metal working machine tool setting) may be highly portable in regions with dense concentration of firms employing respective skills. This is very much in line with spatial agglomeration argument that propensity of poaching is related with density of firms in the region (Brunello and Gambarotto, 2007; Bellmann, Hohendanner and Hujer, 2010). Furthermore, this suggests that portability of skills is dynamic: it should be established at 
each case individually and depends on the level of unemployment, competitive strategies of firms, etc.

This has several implications. First, it implies that portability of skills could be conceptualised as a continuous variable that could range from one to a large number of firms that make use of acquired skills. This allows transcending general - specific skills dichotomy. Second, while the reasons for low portability of skills in regional labour markets could be different (for e.g. high unemployment, weak signalling power of acquired qualifications and labour market segmentation), the outcomes are likely to be similar: the lower portability of skills, the more compressed are external wages and the higher incentives for firms to invest in training. Hence, the hypothesis:

H.2.The smaller the number of firms that could make use of employees' skills, the higher propensity of firmsponsored training.

\section{Which skills matter?}

The second question refers to the extent to which employers' incentives to provide training depend on: a) types (or value) of skills developed during training or b) overall set of skills an employee has. Since Becker the literature has focused on the former. Within this strand of thought, there are two alternatives according to the above discussed dimensions. If we assume that labour market structure affects the value of skills (likely to be) acquired in education and training, then the incentives of firms depend on relevance of education/training to other firms (see North/West corner of Table 1). Alternatively, vast literature focused on contents of education/training by constructing dichotomies based on general v.s. firmspecific training. This is problematic, because theoretically and empirically it is virtually impossible to separate purely firm-specific from general training. Even the broadest curriculum is developed and applied within a given context and inevitably becomes firm specific. Development of firm-specific skills is also likely to lead to acquisition of broader skills (for example, learning to learn). This led literature (Balmaceda, 2005; Kessler and Lulfesmann, 2006) to argue that there are strategic complementarities between general and specific skills: in the absence of market frictions firms could still provide general training as long as it is coupled with acquisition of specific skills. However, if two types of training cannot be conceptually and empirically distinguished, the explanatory power of such arguments to explain variation in firm-funded training should be rather low. Nevertheless, recognising the importance of such arguments in the literature, we shall test hypothesis that:

H3. Education/training valuable to a large number of firms is not likely to be funded by employer.

Alternatively, one could argue that employers' incentives to provide training depend on the portability of overall set of skills an employee has rather than the skills (likely to be) acquired in education/training. In other words the dilemma refers to choice of recipients of sponsored training rather than choice of type of training to be funded. The rationale behind this is that external wage depends on overall set of skills a worker has. If the overall set of skills an employee has is of no use to other employers, then investment in acquisition of even the broadest skills, is not likely lead to growth in external wage commensurable to growth in productivity. On the other hand, if a worker has a large number of outside options then employers returns from investments are likely to be zero and training will not be provided. This largely supports hypothesis no. 2 .

\section{Empirical strategy}

Empirical analysis of training in Europe is limited by lack of comparative datasets (Bassanini et al., 2005). Continuing Vocational Training Survey (CVTS) is an employer survey that provides information on training firms, but little information on trainees and employee funded training. International Adult Literacy Survey provides considerable breadth of individual-level data, but so far covers only a small share of EU Members. To address these problems, this paper uses use data from the $5^{\text {th }}$ wave of European Social Survey carried out in 20102011 in 26 European countries. The main benefit of this data set is that it includes questions on participation in education or training and perceived usefulness of such training as well as overall set of respondents' skills to other employers. Perceptions are particularly important in this case, since they reveal how employees value their chances of switching employers. While perceptions of managers of firms could provide a more direct measure, employers' surveys for e.g. (CVTS) do not contain information about training that was not sponsored by firm. The sample used in the analysis consists of 8797 observations and includes individuals employed in private firms in 21 EU Member State, plus Norway and Switzerland ${ }^{1}$.

The questions used to measure firm-sponsored training asked, whether an individual during the last 12 months has participated in any course, lecture or conference to improve knowledge or skills for work and what proportion of costs were paid for by employer. Both dependent variables are dichotomous and measure, whether an individual participated in education/training that was at least partially funded by employer. The first one defines non-recipients as the ones who covered the costs themselves and the ones who did not participate in education/training. The second dependent variable defines non-recipients only as individuals, who participated in education/training, but covered full costs themselves. Overall, less than a quarter of respondents participated in such education/training; $26,5 \%$ of participants paid the full cost themselves.

The independent variables seek to capture different dimensions of skills portability. The first one measures occupational tenure. The question asked was: 'including all jobs you have ever had, how many years in total have you been doing the kind of work you currently do?'. The kind of work is defined in terms of occupations. The second variable is dichotomous and measures whether a respondent has graduated from vocational or academic

\footnotetext{
${ }^{1}$ Israel, Ukraine and Russian Federation are not included in the analysis due to large differences of these economies from European Free Trade Association and the EU.
} 
education (irrespective of the level of education). The third independent variable seeks to capture outside options: does the respondent know other employers who would have good use of that (s)he learned in present job. The skills are considered as portable, if the respondent knows 'many' or 'some' and specific, if 'one or two' or 'none'. The last independent variable seeks to capture portability of skills acquired in courses, lectures, etc. attended during the last 12 months. The acquired skills are portable, if respondent thinks that they would be 'very useful' or 'quite useful', if (s)he wanted to go and work for a different employer or firm. Note that the third independent variables address portability of overall skills-mix, while the fourth one captures only the skills acquired in education/training.

The 'traditional' controls include: age, gender, type of contract (limited or unlimited duration), occupation (measured according to ISCO and responsibility for supervision of employees), number of years in full time education, economic sector and size of a firm. To control for goodness of match between a worker and the firm, a continuous variable measures how satisfied a worker is with his(her) current job. The Likert scale ranges from 1 (extremely dissatisfied) to 10 (extremely satisfied). Workplaces could also differ in terms of additional training that is needed beyond minimum necessary entry standards. To capture this, the analysis includes a control variable that is based on the following question: 'if somebody with the right education and qualifications replaced you, how long would it take them to learn the job reasonably well?' It is assumed that work does not require considerable training, if this period is less than one month.

To account for differences in labour market institutions dummies are used for the following groups of countries: social democratic (Denmark, Finland, Sweden and Norway), corporatist (Belgium, Germany, the Netherlands, France and Switzerland), Mediterranean (Cyprus, Croatia, Greece, Spain and Portugal) and postcommunist (Bulgaria, the Czech Republic, Estonia, Hungary, Lithuania, Poland, Slovenia and Slovakia). The literature (for e.g. Booth, Francesconi and Zoega, 2003; Dustmann and Schonberg, 2009) also argues that specific labour market institutions such as trade unions set wage floors, which induce firms to pay less skilled workers more than their marginal product. This creates incentives for firms to invest in training and reap the surplus arising from higher productivity. Hence, a dummy on membership in trade union is used to capture these effects.

Operationalisation and coding of the variables as well as descriptives are discussed more extensively in Appendix A. Since the dependent variable is dichotomous and its distribution is far from normal, empirical test uses binary logistic regression.

Table 2

Results of analysis

\begin{tabular}{|c|c|c|c|}
\hline & \multicolumn{2}{|c|}{$\begin{array}{l}\text { All respondents employed in private } \\
\text { firms }\end{array}$} & \multirow{2}{*}{$\begin{array}{c}\begin{array}{c}\text { Only respondents who participated } \\
\text { in education/training }\end{array} \\
\operatorname{Exp}(\mathrm{B}) \text { for Model } 3\end{array}$} \\
\hline & $\begin{array}{l}\text { Exp (B) for Model } \\
1\end{array}$ & $\begin{array}{l}\text { Exp (B) for } \\
\text { Model } 2\end{array}$ & \\
\hline Occupational tenure & .994 & & \\
\hline Vocational education & 1.067 & & \\
\hline Number of outside options & & $1.379 * *$ & \\
\hline $\begin{array}{l}\text { Value of education/training to other } \\
\text { employers }\end{array}$ & & & .855 \\
\hline Corporatist & $1.483 * *$ & $1.489 * *$ & 1.173 \\
\hline Social democratic & $2.496 * *$ & $2.470 * *$ & $1.716^{*}$ \\
\hline Mediterranean & $.652 * *$ & $.649 * *$ & .794 \\
\hline Post-socialist & $.710 * *$ & $.781 *$ & .827 \\
\hline Male & $1.124 * *$ & $1.139 *$ & $1.313^{*}$ \\
\hline Age & $.986 * *$ & $.984 * *$ & $1.015^{*}$ \\
\hline Education & $1.084 * *$ & $1.083 * *$ & $.961 *$ \\
\hline Small firms & $.688 * *$ & $.676^{* *}$ & $.609 * *$ \\
\hline High skilled white collar & $1.948 * *$ & $1.875 * *$ & $1.500 * *$ \\
\hline Boss & $.528 * *$ & $.542 * *$ & $.690 * *$ \\
\hline Satisfaction & $1.119 * *$ & $1.110 * *$ & $1.086 * *$ \\
\hline Trade Union & $1.350 * *$ & $1.379 * *$ & 1.118 \\
\hline Unlimited duration contract & $1,216^{*}$ & $1,224 *$ & $1.640 * *$ \\
\hline Work specificity & $1.771 * *$ & $1.671 * *$ & $1.848 * *$ \\
\hline Constant & $.238^{* *}$ & $.110 *$ & 1.939 \\
\hline Nagelkerke R Square & .282 & .279 & .122 \\
\hline Number of obs. & 9108 & 8797 & 3255 \\
\hline
\end{tabular}

Source: own computation based on $5^{\text {th }}$ wave of European Social Survey.

Notes: * significant at .05 level; ** significant at .005 level. In all models dummies for economic sector (agriculture, manufacturing, services) were not statistically significant; only high skilled white collar occupations were statistically significant. 


\section{Results}

The first group of models (Model 1-2) includes a sample of all respondents, employed in private firms. The dependent variable captures whether an individual participated in firm-sponsored training. 'Non-participants' include individuals who covered the costs themselves and the ones, who did not participate in any training at all. Model 1 tests the first hypothesis: individuals with short tenures and academic education should face lower odds of receiving firm-funded training than employees with long tenures and vocational training. As results provided in Table 2 suggest, both variables are statistically insignificant: occupational tenure and type of education cannot explain incidence of firm-sponsored training.

Model 2 tests the second hypothesis: the smaller the number of firms that could make use of employees' skills, the higher propensity of firm-sponsored training. The results show that there is a statistically significant relationship, but the signs are not as expected. Explanatory variable used in model 2 captures perceptions on the number of firms that could make use of the set of skills acquired in current job. The results suggest that if a respondent knows 'some' or 'many' firms the odds of receiving firm-funded training increase by a factor of 1,379 (or by $37,9 \%$ ). Hence, it seems that individuals with larger number of outside options are more likely to receive firmfunded training, which is in contrast to what the theory predicts.

Control variables used in Models 1-2 also convey interesting information. The odds of receiving firmsponsored training are considerably higher in social democratic and corporatist countries, but lower in mediterranean and post-socialist countries. Most probably not surprisingly, high skilled white collar occupations significantly increase the odds of receiving training. The results also confirm the hypothesis in the literature that membership in trade union increases the odds of receiving firm-sponsored training. In line with the previous findings, the results also suggest that small firms are less likely to train. Economic sector provide to be statistically insignificant and were not included in the model.

Model 3 includes a subsample of population that participated in education/training. Here the dependent variable distinguished between those, whose costs were at least partially covered by the employing firm and individuals who paid the full cost of training themselves. The model tests the following hypothesis: education/training valuable to a large number of firms is not likely to be funded by employer. As the results suggest, specificity of acquired training is not statistically significant. A closer look at the data reveals that employers frequently invest in education and training that is of high value to other firms: $85,1 \%$ of respondents, whose costs were entirely covered by employers, argued that the acquired knowledge would be very and quite useful, if they changed employer. Conversely, 17,2 \% of respondents who covered the full costs of education/training themselves, argued that the acquired skills are not very useful or not useful at all to other employers. This stands in sharp contrast to expectations in the literature arguing that firms should invest only in skills that are of no use to other employers, while employees should invest in skills that are highly valuable to a large number of firms.

\section{Conclusions and discussion}

The paper sought to test the argument in the literature that propensity of firm-sponsored training depends on portability of skills. The latter concept is far from problematic. To capture its diverse meanings portability of skills was operationalised in three ways: type of training (vocational or academic) acquired and occupational tenure, number of outside options/ease of switching employers and value of skills acquired during education/training to other employers. Empirical tests revealed that type of training acquired and occupational tenure and well as value of training to other employers are statistically insignificant. The number of outside options increases the odds of receiving firm-funded training. This runs counter to the hypothesis found in the literature (for e.g. Acemoglu and Pischke, 1999a, 1999b).

There are two important limitations that caution broad generalisations. First, due to the structure of the data, the test did not assess the effects of portability of skills on wage compression. Hence, the hypotheses found in the literature were not fully tested. Second, the empirical test did not adequately control for self-selection based on abilities. It is highly likely that the most talented individuals are selected for firm sponsored training (due to higher returns) and due to their talent also have larger number of outside options. If that is indeed the case, the question still remains: why do firms train?

The mainstream literature implicitly assumes that productivity function is identical in all firms. If we relax this assumption, then it is easy to see, why training does not yield the same returns in a heterogeneous group of firms. The ones operating at productivity frontier can reap the highest profits from investments in skills and can also offer highest level of wages. Here the structure of wages is compressed precisely, because no other firm can make better use of trained workers. Conversely, less productive firms do not have incentives to invest in training, because the returns to productivity will be lower and the threat of poaching higher. Note that this argument would still hold even if we assumed that the labour market is frictionless and all 'skills' (signals) were homogenous (relevant to all firms).

Other results are compatible with a the findings in previous studies: most of the training is paid for by employers, small firms are less likely to provide training, firms relying on advanced technologies are more prone to invest in skills of employees (Lynch and Black, 1995), firms in Northern and Western parts of Europe are more likely to train than firms in Mediterranean and postsocialist countries (Bassanini et al., 2005), members of trade unions are more likely to receive firm-funded training (Dustmann and Schonberg 2009). Overall these findings seem to suggest that the role of labour market institutions in compressing wages and inducing firmsponsored training could be very important. 


\section{Acknowledgements}

The research was carried out during postdoctoral research fellowship awarded by the Research Council of Lithuania. Postdoctoral fellowship is funded by the European Union Structural Funds project 'Postdoctoral Fellowship Implementation in Lithuania'.

\section{References}

1. Acemoglu, D., \& Pischke, J.S. (1999a). Beyond Becker: Training in Imperfect Labour Markets. The Economic Journal, 109, (453), F112-F142. http://dx.doi.org/10.1111/1468-0297.00405

2. Acemoglu, D., \& Pischke, J.S. (1999b). The structure of wages and investment in general training. Journal of Political Economy, 107, (3), 539-572. http://dx.doi.org/10.1086/250071

3. Acemoglu, D., \& Pischke, J.S. (2003). Minimum Wage and Onthe-Job Training. Research in Labor Economics, 22, 159-202. http://dx.doi.org/10.1016/S0147-9121(03)22005-7

4. Balmaceda, F. (2005). Firm-Sponsored General Training. Journal of Labor Economics, 23, (1), 115-133. http://dx.doi.org/10.1086/425435

5. Barron, J. M., Berger, M. C., \& Black, D. A. (1997). On-the-jobT raining. Kalamazoo: W. E. Upjohn Institute for Employment Research.

6. Bassanini, A., \& Brunello, G. (2003). Is Training More Frequent When Wage Compression is Higher? Evidence from the European Community Household Panel. IZA Discussion Paper No. 839, August.

7. Bassanini, A., Booth, A., Brunello, G., De Paola, M., \& Leuven, E. (2005). Workplace Training in Europe, IZA DP No. 1640.

8. Becker, G. (1964/1993). Human Capital: A Theoretical and Empirical Analysis, with Special Reference to Education (3rd ed.). Chicago, London: University of Chicago Press.

9. Bellmann, L., Hohendanner, Ch., \& Hujer, R. (2010). Determinants of Employer-Provided Further Training: A Multi-Level Approach, IZA Discussion Paper No. No. 5257, October.

10. Bishop, J. H. (1991). On-the-job training of new hires. In D. Stern, J.M. Ritzen (eds.). Market Failure in Training? New Economic Analysis and Evidence on Training of Adult Employees. Berlin: Springer Verlag, 61-98. http://dx.doi.org/10.1007/978-3-64276986-3_4

11. Bishop, J. H. (1996). What we know about employer-provided training: a review of the literature. Cornell University, Center for Advanced Human Resources Studies Working Paper 96-09.

12. Booth, A., \& Bryan, M. L. (2002). Who Pays for General Training? New evidence for British Men and Women, IZA Discussion Paper No. 486, April.

13. Booth, A., Francesconi, M., \& Zoega, G. (2003). Unions, Workrelated Training and Wages: Evidence for British Men. Industrial and Labor Relations Review, 57, (1), 68-91. http://dx.doi.org/10.2307/3590982

14. Brunello, G., \& De Paola, M. (2007). Training and economic density: Some evidence form Italian provinces. Labour Economics, 15, (1), 118-140. http://dx.doi.org/10.1016/j.labeco.2006.10.001

15. Culpepper, P. D. (2007). Small States and Skill Specificity Austria Switzerland, and Interemployer Cleavages in Coordinated Capitalism. Comparative Political Studies, 40, (6), 611-637. http://dx.doi.org/10.1177/0010414006295927

16. Dustmann, Ch., \& Schönberg, U. (2009). Training and Union Wages. The Review of Economics and Statistics, 91, (2), 363-376. http://dx.doi.org/10.1162/rest.91.2.363

17. Estavez-Abe, M., Iversen, T., \& Soskice, D. (2001). Social Protection and the Formation of Skills: A Reinterpretation of the Welfare State. In P. A. Hall, D. Soskice (eds.). Varieties of Capitalism: the Institutional Foundations of Comparative Advantage. Oxford, NY: Oxford University Press. http://dx.doi.org/10.1093/0199247757.003.0004

18. Franz, W., \& Soskice, D. (1995). The German apprenticeship system. In Buttler et al., (eds.). Institutional Frameworks and Labour Market Performance. Comparative Views on the German and U.S. Economies, 208-34. London: Routledge.

19. Geel, R., Mure, J., \& Backes-Gellner, U. (2011). Specificity of occupational training and occupational mobility: an empirical study based on Lazear's skill-weights approach. Education Economics, 19, (5), 519-535. http://dx.doi.org/10.1080/09645291003726483

20. Grossberg, A. J., \& Sicilian, P. (1999). Minimum Wages, On-theJob Training, and Wage Growth. Southern Economic Journal, 65, (3), 539-556. http://dx.doi.org/10.2307/1060814

21. Harhoff, D., \& Kane, Th. (1997). Is the German apprenticeship system a panacea for the U.S. labor market? Journal of PopulationE conomics, $10, \quad 171-96$. http://dx.doi.org/10.1007/s001480050037

22. Kessler, A. S., \& Lulfesmann, Ch. (2006). The Theory of Human Capital Revisited: on the Interaction of General and Specific Investments. The Economic Journal, 116, 903-923. http://dx.doi.org/10.1111/j.1468-0297.2006.01116.x

23. Leighton, L., \& Mincer, J. (1981). The Effects of Minimum Wages on Human Capital Formation. In S. Rottenberg (ed.). The Economics of Legal Minimum Wages. Washington: American Enterprise Inst. Public Policy Res.

24. Lynch, L. M., \& Black, S.E. (1995). Beyond the Incidence of Training: Evidence from a National Employers Survey, NBER Working Papers 5231.

25. Neumark, D., \& Wascher, W. (2001). Minimum Wages And Training Revisited. Journal of Labor Economics, 19, (3), 563-595. http://dx.doi.org/10.1086/322073

26. Steedman, H. (1993). The economics of youth training in Germany. The Economic Journal, 103, 1279-91. http://dx.doi.org/10.2307/2234254

27. Thelen, K. (2007). Skill Formation and Training. In G. Joneas, J. Zeitlin (eds.). The Oxford Handbook of Business History. Oxford, NY: Oxford University Press.

28. Wiji, A., Booth, A. J., \& Bryan, M. L. (2004). Training and the new minimum wage. Economic Journal, 114, (494), C87-C94. http://dx.doi.org/10.1111/j.0013-0133.2003.00197.x

\section{Data sets:}

- $\quad$ ESS Round 5: European Social Survey Round 5 Data (2010). Data file edition 3.0. Norwegian Social Science Data Services, Norway - Data Archive and distributor of ESS data.

\section{Ž. Martinaitis}

\section{Darbdavių investicijos ị darbuotojų mokymą: gebejjimų} perkeliamumo testas

\section{Santrauka}

Organizuodamos praktikas, pameistrystes ir investuodamos i savo darbuotojų mokymą, įmonès vaidina svarbų vaidmenį mokymosi visą gyvenimą sistemoje. Švietimo ekonomikos literatūroje keliamas klausimas: kodèl ir kada ịmonès bus linkusios padengti dali darbuotoju mokymosi kaštų? Gary Becker (1993) teigè, kad įmonių sprendimas priklauso nuo gebejjimu (angl. skills) perkeliamumo (angl. transferability). Imonès nèra linkusios investuoti ị bendruosius gebejjimus, kurie yra naudingi daugeliui įmonių. Priežastis - apmokytas darbuotojas bus arba perviliotas kitu ịmonių, arba mokymus finansavęs darbdavys turès mokèti darbo užmokestị, atitinkantị asmens produktyvumą (ir kitų imoniu siūlomą darbo užmokesti). Tokiu atveju mokymus finansavusi įmonè neatgautų investicijų, skirtų darbuotojo mokymui. Kita vertus, jei mokymosi metu igyjami specifiniai gebejjimai, kurie yra neaktualūs kitoms imonėms, investuojantis darbdavys gali mégautis monopsoniniu pelnu, kurị sudaro skirtumas tarp ribinio mokymuose dalyvavusio asmens produktyvumo ir darbo užmokesčio augimo. Tad darbdaviai turètu investuoti tik ị specifinių, o darbuotojai ị bendrụų gebejjimų ugdymą. Vèlesniuose darbuose (Acemoglu ir Pischke, 1999a, 1999b) teigiama, kad netobuloje darbo rinkoje darbdaviai gali investuoti net ir $i$ bendruju gebèjimų ugdymą. Priežastis - darbo rinkos frikcijos (pvz., transakcijų kaštai, nepankama informacija) ir institucijos (pvz., minimalus darbo užmokestis, koordinuotos derybos dèl darbo užmokesčio „suspaudžia“ darbo užmokestị taip, kad $\mathrm{f}(\tau)>\mathrm{w}(\tau)>\mathrm{v}(\tau)$. Čia $\mathrm{f}(\tau)$ žymi asmens ribini produktyvumą kaip gebėjimu funkciją, $\mathrm{w}(\tau)$ darbo užmokesčio dabartinejje ịmonèje funkciją, o v $(\tau)$ darbo užmokesčio kitose ịmonèse funkciją.

Nepaisant plačios akademinès diskusijos svarbiausias nepriklausomas kintamasis - gebejjimų perkeliamumas - lieka nepakankamai konceptualizuotas ir operacionalizuotas. Tai galètų paaiškinti, kodèl empirinių darbų šioje srityje iš esmès nèra. Todèl šiame straipsnyje siekiama aptarti svarbiausias alternatyvas, kaip gali būti 
apibrèžtas gebejimu perkeliamumas ir empiriškai patikrinti akademinėje literatūroje pateikiamas hipotezes.

Gebèjimy̨ perkeliamumą galima konceptualizuoti dviejose dimensijose: pagal tai, kas lemia (ne)perkeliamumą (darbo rinkos struktūra ar mokymosi turinys?) ir pagal tai, kokie gebėjimai yra svarbūs (visu asmens turimu gebejimu perkeliamumas ar tik tų, kurie igyti mokymosi metu?). Atitinkamai straipsnyje iškeltos trys hipotezès, kurios sieja galimybes, kad įmone finansuos asmens mokymąsi, su: (a) igyto išsilavinimo tipu (akademinis ar profesinis) ir vidutine darbo vienoje imonejje trukme (gebejimu perkeliamumą lemia mokymosi turinys ir gebejjimu visuma); (b) įmoniu, kuriose asmuo galètu pritaikyti turimus gebejjimus, skaičiumi (perkeliamumą lemia darbo rinkos situacija ir gebėjimų visuma); (c) mokymų metu igytų gebėjimų svarba kitoms įmonèms (perkeliamumą lemia mokymosi turinys ir tik tie gebejjimai, kurie igyti mokymosi metu).

Empirinis tyrimas parodè, kad nèra jokiu statistiškai reikšmingu ryšių tarp galimybių dalyvauti įmonès finansuojamuose mokymuose ir igyto išsilavinimo tipo, vidutinès darbo vienoje i̇moneje trukmès bei mokymų metu ịgytų gebejjimų svarbos kitoms įmonèms. Taigi pirmoji ir trečioji hipotezès atmestos. Rezultatai taip pat rodo, kad yra statistiškai reikšmingas ryšys tarp dalyvavimo ịmonès finansuotuose mokymuose bei asmens galimybiu keisti darbą: jei asmuo gali savo turimus gebejjimus pritaikyti ir kitose i̇monèse, galimybès, kad darbdavys investuos $\mathfrak{i}$ jo mokymą, padideja 37,8 proc. Tad gauti rezultatai prieštarauja pastaruosius 50 metu vykusios akademinès diskusijos metu keliamoms hipotezėms. Tai galèjo lemti endogeniškumo problema: ịmonès yra labiau linkusios investuoti $i$ talentingesnius, labiau motyvuotus darbuotojus, tačiau šios savybès taip pat leidžia pastariesiems tikètis geresnių karjeros galimybių kitose įmonèse.
Kiti rezultatai atitinka anksčiau atliktuose tyrimuose (Lynch ir Black, 1995; Bassanini et al., 2005; Dustmann and Schönberg 2009) gautas išvadas: didžiają užimtujų mokymosi kaštų dalį padengia darbdaviai, mažos i̇monès gerokai rečiau finansuoja darbuotoju mokymąsi nei didžiosios, ịmonès Šiaurès ir Vakarų Europoje dažniau investuoja ị darbuotojų mokymąsi nei Pietų Europos ir pokomunistinių šalių įmonès, o profesinèms sajungoms priklausantys darbuotojai dažniau dalyvauja mokymuose nei joms nepriklausantys asmenys.

Hipotezès tikrintos naudojant Europos socialinio tyrimo 5-osios bangos duomenimis. Apklausa atlikta 2010-2011 m. 26 Europos valstybėse. Šio tyrimo metu naudoti duomenys apima visas (21) apklausoje dalyvavusias ES nares, Norvegiją ir Šveicariją. Stebèjimų skaičius -8797.

Reikšminiai žodžiai: švietimo ekonomika, žmogiškasis kapitalas, švietimo finansai, gebèjimų perkeliamumas.

First received: May, 2014

Accepted for publication: June, 2014 
APPENDIX A

\begin{tabular}{|c|c|c|}
\hline Variable & Coding & Descriptives \\
\hline $\begin{array}{l}\text { Participation in firm-funded } \\
\text { training (1) }\end{array}$ & $\begin{array}{l}0=\text { did not participate or participated, but firm did } \\
\text { not pay; } \\
1=\text { participated in firm-funded course, lecture, } \\
\text { conference. }\end{array}$ & \multirow{2}{*}{$\begin{array}{l}16,9 \% \text { participated in firm funded } \\
\text { course, conference or lecture. The } \\
\text { remaining } 6,2 \% \text { participated, but paid } \\
\text { the entire cost themselves and } 76,9 \text { did } \\
\text { not participate. }\end{array}$} \\
\hline $\begin{array}{l}\text { Participation in firm-funded } \\
\text { training (2) }\end{array}$ & $\begin{array}{l}0=\text { participated, but firm did not pay; } \\
1=\text { participated in firm-funded course, lecture, } \\
\text { conference. }\end{array}$ & \\
\hline Occupational tenure & $\begin{array}{l}\text { Scale variable, measuring number of years doing } \\
\text { same kind of job. }\end{array}$ & $\begin{array}{l}\text { Mean }=12,2, \text { median }=10, \text { std. } \\
\text { deviation }=10,433\end{array}$ \\
\hline Vocational education & $\begin{array}{l}0=\text { academic education (ISCED1, General ISCED2, } \\
\text { general ISCED3, general ISCED4, ISCED 5-6) } \\
\text { 1=vocational education (pre-vocational and } \\
\text { vocational ISCED2, Vocational ISCED3, } \\
\text { vocational ISCED 4) }\end{array}$ & $43,7 \%$ with vocational education. \\
\hline Number of outside options & $\begin{array}{l}0=\text { knows one or two or none other employers who } \\
\text { would make good use of what learnt in present job; } \\
1=\text { know many or some. }\end{array}$ & $\begin{array}{l}74,9 \% \text { of respondents know many or } \\
\text { some employers who would make good } \\
\text { use of what learnt in present job. }\end{array}$ \\
\hline Ease of getting similar job & $\begin{array}{l}0=\text { extremely difficult; } \\
10=\text { extremely easy }\end{array}$ & $\begin{array}{l}\text { Mean }=4,54, \text { median }=5, \text { std. } \\
\text { deviation }=2,724\end{array}$ \\
\hline $\begin{array}{l}\text { Specificity of acquired } \\
\text { training }\end{array}$ & $\begin{array}{l}0=\text { knowledge and skills acquired in courses, } \\
\text { lectures, etc. attended during the last } 12 \text { months } \\
\text { would be very useful or rather useful if changed } \\
\text { firm/employer; } \\
1=\text { would not be very useful, would not be useful at } \\
\text { all }\end{array}$ & $\begin{array}{l}15 \% \text { reported that acquired skills and } \\
\text { knowledge would not be very useful or } \\
\text { would not be useful at all. }\end{array}$ \\
\hline Sector or economy & $\begin{array}{l}\text { Dummy variables for agriculture, forestry and } \\
\text { mining; manufacturing; services }\end{array}$ & $\begin{array}{l}4,4 \% \text { in agriculture, forestry and } \\
\text { mining; } 25,6 \% \text { in manufacturing; } 70 \% \\
\text { in services. }\end{array}$ \\
\hline Country groups & $\begin{array}{l}\text { Dummy variables for Corporatist (Belgium, } \\
\text { Germany, the Netherlands, France and } \\
\text { Switzerland), Social democratic (Denmark, } \\
\text { Finland, Sweden and Norway), Liberal (Ireland and } \\
\text { UK), Mediterranean (Cyprus, Croatia, Greece, } \\
\text { Spain and Portugal) and Post-communist (Bulgaria, } \\
\text { the Czech Republic, Estonia, Hungary, Lithuania, } \\
\text { Poland, Slovenia and Slovakia) }\end{array}$ & $\begin{array}{l}\text { The distribution of respondents in the } \\
\text { sample by group of countries is as } \\
\text { follows: } 23,9 \% \text { Corporatist, } 15,3 \% \\
\text { Social democratic, } 12,2 \% \text { Liberal, } 20 \\
\% \text { Mediterranean, } 28,5 \% \text { Post-socialist. }\end{array}$ \\
\hline Male & Dummy for males & $52,9 \%$ males \\
\hline Age & Scale variable & Mean $=46,4$. Median $=45$ \\
\hline Education & $\begin{array}{l}\text { Scale variable: number of years in full-time } \\
\text { education and training. }\end{array}$ & $\begin{array}{l}\text { Mean: } 12,22 \text {; median: } 12 \text {; std deviation: } \\
3,8 \text {. }\end{array}$ \\
\hline Small firms & $\begin{array}{l}\text { Dummy variable for small firms (less than } 24 \\
\text { employees) }\end{array}$ & $\begin{array}{l}34,9 \% \text { of respondents worked in small } \\
\text { firms. }\end{array}$ \\
\hline Occupation & $\begin{array}{l}\text { Dummies for skilled white collar occupations } \\
\text { (ISCO } 1,2 \text { and 3); low skilled white collar workers } \\
\text { (ISCO } 4 \text { and 5), high skilled blue collar workers } \\
\text { (ISCO } 6 \text { and 7) and low skilled blue collar workers } \\
\text { (ISCO } 8 \text { and 9) }\end{array}$ & $\begin{array}{l}\text { High skilled white collar }-28,5 \% \\
\text { Low skilled white collar }-28,6 \% \text {; } \\
\text { High skilled blue collar }-18,5 \% \\
\text { Low skilled blue collar }-24,6 \%\end{array}$ \\
\hline Boss & $\begin{array}{l}0=\text { not responsible for supervising other employees; } \\
1=\text { responsible for supervising other employees }\end{array}$ & $\begin{array}{l}26,3 \% \text { responsible for supervision of } \\
\text { other employees. }\end{array}$ \\
\hline Satisfaction & $\begin{array}{l}\text { Scale from } 1 \text { (extremely dissatisfied with present } \\
\text { job) to } 10 \text { (extremely satisfied) }\end{array}$ & $\begin{array}{l}\text { Mean: 7,24, Median: } 8 \text {, Std. deviation: } \\
1,9\end{array}$ \\
\hline Trade Union & Dummy for membership in trade union & $14,4 \%$ members of trade unions. \\
\hline Unlimited duration contract & Dummy for unlimited duration contract & $\begin{array}{l}82,3 \% \text { with contracts with unlimited } \\
\text { duration }\end{array}$ \\
\hline Work specificity & $\begin{array}{l}\text { Question asked in the survey: 'if somebody with the } \\
\text { right education and qualifications replaced you, } \\
\text { how long would it take them to learn the job } \\
\text { reasonably well?'. Coding: } \\
0=\text { less than one month } \\
1=\text { one month or more }\end{array}$ & $67,6 \%$ one month or more. \\
\hline
\end{tabular}

